\title{
Functional response of Phytoseiulus persimilis Athias-Henriot to Tetranychus urticae Koch: effects of prey life stages and temperature
}

Md. Fazlul Hoque, Md. Wahedul Islam and M. Khalequzzaman* Institute of Biological Sciences, University of Rajshahi, Rajshahi 6205, Bangladesh

*Corresponding author email: kzaman@ru.ac.bd

\begin{abstract}
This paper examines the effect of density and temperature on the functional response of adult female Phytoseiulus persimilis to different life stages of the spider mite, Tetranychus urticae. The functional response was determined using functional response assay technique with plant leaf discs an arena. We conducted a logistic regression of the proportion of prey consumed as a function of initial prey density to identify functional response types, and used nonlinear leastsquares regression and the random predator equation to estimate attack rates and handling times. In all the cases number of adult male prey attacked by female predator were greater than adult female prey. $P$. persimilis consumed more eggs and larvae than other stages of prey. Female predator consumed adult prey at each temperature which generally increased with prey density initially but leveled off at higher prey densities. The highest number of eggs, larvae and nymphs consumed by predator in 24 hours was $16.3 \pm 0.42,9.9 \pm 0.59$ and $9.5 \pm 0.40$ respectively whereas the highest number of eggs, larvae and nymphs consumed by a single female in 48 hours was 19.5 $\pm 1.15,18.6 \pm 0.62$ and $13.3 \pm 0.65$ respectively. Handling time generally decreased with temperature whereas successful attack rate increased with temperature except at $30^{\circ} \mathrm{C}$. Judging by a/Th values, $P$. persimilis was most efficient against $T$. urticae at $30-35^{\circ} \mathrm{C}$, about half as efficient at $25^{\circ} \mathrm{C}$ and performed poorly at $20^{\circ} \mathrm{C}$. Again, from a/Th values, $P$. persimilis was most efficient against $T$. urticae in egg stage, about half as efficient at larva and nymph stages and performed poorly at adult stage.
\end{abstract}

Key words: Phytoseiulus persimilis, Tetranychus urticae, functional response, predation, temperature.

\section{Introduction}

The dynamics of predators and their prey is one of the more extensively studied areas of ecological dynamics. This is particularly true for insects, due to their significant impact on global food production and human health and because their short life cycles and small size make them highly amenable to laboratory study (Taylor, 1984). It is widely believed that in most animal species, population growth rate is a decreasing function of density (Turchin, 1995). Thus, per capita growth rate is negatively associated with present and/or past population densities (negative density dependence). Phytophagous insect populations exist at relatively low to extremely high density. Top-down factors (i.e. natural enemies) can act to depress herbivore population size, usually well below the host-plant's carrying capacity (Cappuccino, 1992; Hunter \& Elkinton, 1999). Alternatively, bottom-up factors, such as plant defenses, can control herbivore population growth (Hunter \& Price, 1992).

The role of predators in regulating or suppressing prey populations has been studied extensively by population biologists. Although the dynamics of most predator-prey relationships are complex, the functional response of predators, or the relationship between the number of prey consumed per predator and prey density (Solomon, 1949; Holling, 1959), is basic to all predator prey interactions (Hassell, 1978). Complications in the interpretation of predator responses may arise because functional response can be influenced by a number of factors, including: (1) characteristics of predator and prey (Abrams, 1990), (2) characteristics of prey, and (3) attributes of an environment (Huffaker et al., 1970).

Understanding predator prey interactions is crucial if a biological control programme is to be successful. Determining the effects of predation on prey populations is most commonly done through the analysis of functional and numerical responses (Huffaker \& Messenger, 1976). The number of prey attacked can then be used to help predict predator development, survival, and reproduction (Murdoch \& Oaten, 1975). Functional response, as originally described by Solomon (1949), is the change in prey number killed per individual predator per unit time as a function of 
changes in prey density. Early functional response research was conducted by Holling (1959). He formulated the mathematical models to describe predatory responses that were influenced by changes in predator behaviour.

Holling $(1959,1961,1965)$ recognized three types of functional responses: (1) a linear rise to a plateau, typical of filter feeders (type I and II), (2) a curvilinear rise to a plateau (with negatively accelerating rate), characteristic of invertebrate predators (type II and III), and (3) a sigmoid curve also reaching a plateau (with a positive accelerating rate up to the inflection point and thereafter a diminishing rate up to the plateau), typical of those predators with a search image (type III). Mori \& Chant (1966) found a domeshaped response (type IV) for Phytoseiulus persimilis Athias-Henriot attacking Tetranychus urticae Koch. This paper presents the results of a set of experiments examining how the predatory efficiency of $P$. persimilis feeding on different life stages of $T$. urticae, as measured by a functional response, was influenced by prey density and temperature.

\section{Materials and Methods}

T. urticae colonies were maintained on bean leaf which was cultivated in the experimental fields of the Institute of Biological Sciences, University of Rajshahi. Experimental arenas were constructed by placing excised leaf disk from uninfested bean plants placed on petridish $(12 \mathrm{~cm}$ diameter) filled with watery cotton bed in the laboratory.

The eggs, larvae, nymphs and adult males and females were placed on leaf disks at densities of $10,20,30,40,50$ and 60 per disk. Adult T. urticae were transferred directly to arenas from the colonies on the day of the experiments using a fine point brush. Eggs were obtained by placing $T$. urticae adults on pest free bean leaves inside a petridish for two days prior to the experiments. On the day of the experiment egg were transferred from the bean leaves inside the petridish to the arenas. Ten replications of each prey density were deployed for the female predator. The arenas were left undisturbed for at least one hour. They were then examined to determine if any eggs had hatched or adults had laid eggs. One $P$. persimilis was placed at the centre of each of the leaf disks and allowed to feed for eight hours. After eight hours, the number of adult $T$. urticae and cadavers were counted in the adult and larval arenas, and the number of viable egg were counted in the egg arenas to determine how much prey had been consumed. Temperature was recorded hourly. The number of preys consumed by predators at each density were recorded after 24 and 48 hours respectively from the starting of the experiment. Sets of experiments were repeated at $20^{\circ}, 25^{\circ}, 30^{\circ}$ and $35^{\circ} \mathrm{C}$ at prey densities of $10,20,30,40,50$ and 60 maintained in incubators.

In this work formulae of type I and II models of Holling (1959) and type III model of Hassel et al. (1977) were used as below:

$$
\begin{array}{ll}
\text { Type I } & : \quad \mathrm{N}_{\mathrm{a}}=\mathrm{a}^{`} \mathrm{TN} \\
\text { Type II } & : \mathrm{N}_{\mathrm{a}}=\frac{a^{\prime} \mathrm{TN}}{1+\mathrm{a}^{\prime} \mathrm{T}_{h} N} \\
\text { Type III } & : \mathrm{N}_{\mathrm{a}}=\mathrm{N}\left[1-\exp \left(-\mathrm{a}{ }^{\prime}\left[\mathrm{T}-\mathrm{T}_{\mathrm{h}} \mathrm{N}_{\mathrm{a}}\right]\right)\right]
\end{array}
$$

Where $N_{a}$ is the number of prey killed, $N$ is the prey density, $\mathrm{T}$ is the time available for searching during the experiments, $a^{\prime}$ is the search rate and $T_{h}$ is the amount of time the predator handles for each prey killed. Data were analyzed using least square regression by fitting a line through the data point as predicted by the descriptive functional response equation (Fuji et al., 1986)

$$
\mathrm{Y}=\frac{T_{t}}{t_{h}+1 /\left[a^{\prime} X \exp (c X)\right]} .
$$

In this equation $Y$ is the number of attacks per predator, $T_{t}$ is the total time prey is exposed, $X$ is the prey density, $a^{\prime}$ is the search rate and $t_{h}$ is the amount of time the predator handles for each prey killed and $c$ is the facilitation coefficient, which determines the form of the functional response. When $c=a^{\prime} \cdot t_{h}$, the functional response is Pseudo Type I, c $=0$ gives a Type II response, for $\mathrm{c}>$ $a^{\prime} \cdot t_{h}$, the response is type III (Fuji et al., 1986). The data were fitted to the descriptive equation using the LAB Fit Curve Fitting Software by Wilton and Cleide P Silva ver 7.2.42 (1999-2008).

\section{Results}

The daily average number of prey consumed by the $P$. persimilis females at various prey stages and densities of $T$. urticae is shown in Table 1 . In case of all developmental stages of prey generally prey density played a significant role in predation of $P$. persimilis. The average number of preys consumed by $P$. persimilis females feeding on eggs, larvae or nymphs of $T$. urticae gradually increased at an accelerated rate when 10 to 60 preys were provided (Tables 1 and 2). 
Functional responses in all stages of prey in 24 and 48 hours approximated Holling type II model and estimated parameters of functional responses are shown in Tables 1 and 2. Handling time generally increased from egg to adult. Successful attack rate was the highest in the egg stage while it was the lowest in the adult ( + ) stage. Judging by a/Th values, $P$. persimilis was most efficient against $T$. urticae in egg stages, about half as efficient at larvae and nymphal stages and performed poorly at the adult stage. The observed and predicted curves of functional response at different densities at different prey stages in 24 and 48 hours are presented in Figs. 1 - 10.

The number of female preys consumed by female predators at each temperature generally increased with prey density initially but it was leveled off at higher prey densities (Table 3). Functional responses at all temperatures approximated Holling type II model and estimated parameters of functional responses are shown in Table 3. Handling time generally decreased with the increase in temperature, whereas successful attack rate increased with temperature except at $30^{\circ} \mathrm{C}$. Judging by $a / T h$ values, $P$. persimilis was most efficient against $T$. urticae at $30-35^{\circ} \mathrm{C}$, about half as efficient at $25^{\circ} \mathrm{C}$ and performed poorly at $20^{\circ} \mathrm{C}$. The observed and predicted curves of functional response at different densities at different temperatures are presented in Figs. 1114.

Table 1. Functional response parameters of $P$. persimilis (+) to T. urticae in 24 hours

\begin{tabular}{|c|c|c|c|c|c|}
\hline \multirow{2}{*}{ Prey Density } & \multicolumn{5}{|c|}{ Number of prey consumed in the form (mean \pm S.E) } \\
\hline & Egg & Larva & Nymph & Adult $\left(\circlearrowright^{\lambda}\right)$ & Adult $(+)$ \\
\hline 10 & $4.8 \pm 0.42$ & $2.2 \pm 0.20$ & $2.1 \pm 0.23$ & $2.2 \pm 0.33$ & $1.1 \pm 0.18$ \\
\hline 20 & $8.9 \pm 0.50$ & $4.4 \pm 0.27$ & $5.4 \pm 0.48$ & $4.5 \pm 0.45$ & $1.2 \pm 0.20$ \\
\hline 30 & $12.8 \pm 0.57$ & $5.4 \pm 0.31$ & $4.6 \pm 0.27$ & $5.2 \pm 0.33$ & $1.3 \pm 0.26$ \\
\hline 40 & $10.7 \pm 0.56$ & $6.6 \pm 0.43$ & $7.2 \pm 0.55$ & $5.4 \pm 0.48$ & $2.5 \pm 0.27$ \\
\hline 50 & $14.4 \pm 0.69$ & $9.9 \pm 0.59$ & $8.7 \pm 0.30$ & $7.7 \pm 0.47$ & $2.6 \pm 0.31$ \\
\hline 60 & $16.3 \pm 0.42$ & $9.7 \pm 0.37$ & $9.5 \pm 0.40$ & $7.4 \pm 0.43$ & $2.6 \pm 0.27$ \\
\hline$a^{\prime}$ & 0.027 & 0.009 & 0.010 & 0.012 & 0.0036 \\
\hline th & 0.958 & 0.580 & 0.924 & 1.75 & 4.16 \\
\hline$a^{\prime} / T h$ & 0.0281 & 0.0155 & 0.0108 & 0.00685 & 0.000858 \\
\hline C & 0.000948 & 0.0000218 & -0.000153 & -0.000405 & 0.00001625 \\
\hline $\mathrm{R} 2$ & 0.993 & 0.954 & 0.920 & 0.943 & 0.821 \\
\hline - & $0.027 N t$ & $0.009 N t$ & $0.01 N t$ & $0.012 N t$ & $0.0036 N t$ \\
\hline $\mathrm{Na}$ & $\overline{1+0.0258 N t}$ & $1+0.00522 \mathrm{Nt}$ & $\overline{1+0.00924 \mathrm{Nt}}$ & $\overline{1+0.021 \mathrm{Nt}}$ & $1+0.0149 \mathrm{Nt}$ \\
\hline
\end{tabular}

${ }^{*} \mathrm{~N}_{\mathrm{a}}=$ number of preys consumed; $\mathrm{Nt}=$ number of preys available; $\mathrm{T}_{\mathrm{h}}=$ handling time; $\mathrm{a}$ = successful attack rate; $\mathrm{c}=$ facilitation coefficient.

Table 2. Functional response parameters of $P$. persimilis ( $(+)$ to $T$. urticae in 48 hours

\begin{tabular}{|c|c|c|c|c|c|}
\hline \multirow{2}{*}{ Prey Density } & \multicolumn{5}{|c|}{ Number of prey consumed in the form (mean \pm S.E) } \\
\hline & Egg & Larva & Nymph & Adult $(\grave{)}$ & Adult ( $(+)$ \\
\hline 10 & $6.4 \pm 0.43$ & $3.4 \pm 0.31$ & $3.4 \pm 0.37$ & $2.5 \pm 0.45$ & $1.2 \pm 0.20$ \\
\hline 20 & $10.9 \pm 0.66$ & $7.8 \pm 0.47$ & $7.4 \pm 0.27$ & $4.4 \pm 0.31$ & $1.3 \pm 0.26$ \\
\hline 30 & $13.7 \pm 0.37$ & $12.4 \pm 0.75$ & $8.8 \pm 0.42$ & $6.4 \pm 0.37$ & $2.8 \pm 0.33$ \\
\hline 40 & $15.8 \pm 1.30$ & $10.4 \pm 0.62$ & $8.4 \pm 0.50$ & $7.6 \pm 0.50$ & $2.6 \pm 0.27$ \\
\hline 50 & $19.5 \pm 1.15$ & $18.6 \pm 0.62$ & $13.3 \pm 0.65$ & $8.2 \pm 0.55$ & $3.2 \pm 0.33$ \\
\hline 60 & $19.4 \pm 1.25$ & $18.3 \pm 1.19$ & $12.9 \pm 0.86$ & $10.2 \pm 0.42$ & $3.8 \pm 0.39$ \\
\hline$a^{\prime}$ & 0.016 & 0.009 & 0.0089 & 0.0057 & 0.0022 \\
\hline th & 1.561 & 0.614 & 1.784 & 1.935 & 5.564 \\
\hline$a^{\prime} /$ th & 0.0102 & 0.0146 & 0.00498 & 0.00293 & 0.000397 \\
\hline $\mathrm{C}$ & 0.003306 & -0.000058 & -0.000156 & -0.000684 & 0.000073 \\
\hline $\mathrm{R} 2$ & 0.984 & 0.892 & 0.895 & 0.986 & 0.902 \\
\hline Nl & $0.016 \mathrm{Nt}$ & $0.009 \mathrm{Nt}$ & $0.0089 \mathrm{Nt}$ & $0.0057 N t$ & $0.0022 \mathrm{Nt}$ \\
\hline $\mathrm{Na}$ & $\overline{1+0.02497 \mathrm{Nt}}$ & $\overline{1+0.00552 \mathrm{Nt}}$ & $\overline{1+0.01587 \mathrm{Nt}}$ & $\overline{1+0.01103 N t}$ & $1+0.0122408 N$ \\
\hline
\end{tabular}

${ }^{\star} \mathrm{N}_{\mathrm{a}}=$ number of preys consumed; $\mathrm{Nt}=$ number of preys available; $\mathrm{T}_{\mathrm{h}}=$ handling time; $\mathrm{a}$ ' successful attack rate; $\mathrm{c}=$ facilitation coefficient. 
Table 3. Functional response parameters of $P$. persimilis $(+)$ to $T$. urticae $(q)$ at different temperatures.

\begin{tabular}{|c|c|c|c|c|}
\hline \multirow{2}{*}{ Prey Density } & \multicolumn{4}{|c|}{ Number of prey consumed at temperature (mean \pm S.E) } \\
\hline & $20^{\circ} \mathrm{C}$ & $25^{\circ} \mathrm{C}$ & $30^{\circ} \mathrm{C}$ & $35^{\circ} \mathrm{C}$ \\
\hline 10 & $1.3 \pm 0.15$ & $1.7 \pm 0.26$ & $2.1 \pm 0.23$ & $2.2 \pm 0.29$ \\
\hline 20 & $1.4 \pm 0.16$ & $2.0 \pm 0.39$ & $2.2 \pm 0.29$ & $2.4 \pm 0.31$ \\
\hline 30 & $1.5 \pm 0.22$ & $2.1 \pm 0.31$ & $4.2 \pm 0.25$ & $3.1 \pm 0.28$ \\
\hline 40 & $2.7 \pm 0.30$ & $3.1 \pm 0.28$ & $3.2 \pm 0.20$ & $4.1 \pm 0.31$ \\
\hline 50 & $3.2 \pm 0.33$ & $4.1 \pm 0.31$ & $4.8 \pm 0.33$ & $5.1 \pm 0.41$ \\
\hline 60 & $3.1 \pm 0.38$ & $4.0 \pm 0.26$ & $5.0 \pm 0.37$ & $5.0 \pm 0.47$ \\
\hline$a^{\prime}$ & 0.004 & 0.005 & 0.009 & 0.008 \\
\hline th & 3.110 & 2.907 & 3.030 & 2.563 \\
\hline$a^{\prime} /$ th & 0.001238 & 0.00171 & 0.00297 & 0.003055 \\
\hline $\mathrm{C}$ & -0.00037 & 0.000254 & -0.0000759 & -0.0001 \\
\hline $\mathrm{R} 2$ & 0.840 & 0.860 & 0.777 & 0.904 \\
\hline $\mathrm{Na}$ & $0.004 N t$ & $0.005 \mathrm{Nt}$ & $0.009 \mathrm{Nt}$ & $0.008 \mathrm{Nt}$ \\
\hline Na & $\overline{1+0.01244 N t}$ & $\overline{1+0.01453 \mathrm{Nt}}$ & $\overline{1+0.02727 \mathrm{Nt}}$ & $1+0.02050 \mathrm{Nt}$ \\
\hline
\end{tabular}

${ }^{*} \mathrm{~N}_{\mathrm{a}}=$ number of preys consumed; $\mathrm{Nt}=$ number of preys available; $\mathrm{T}_{\mathrm{h}}=$ handling time; $\mathrm{a}$ ' = successful attack rate; $\mathrm{c}$ $=$ facilitation coefficient.

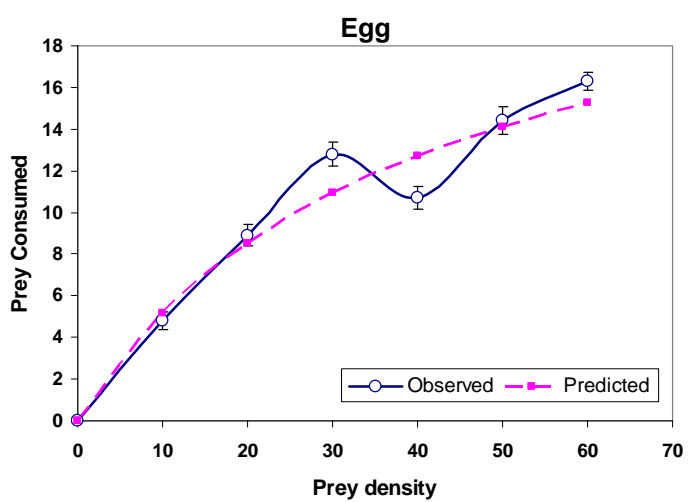

Fig. 1. The functional response of $P$. persimilis $(+)$ to eggs of $T$. urticae in 24 hours. Handling time $\left(T_{h}\right)=$ $0.958 \mathrm{hr} / \mathrm{egg}$, successful attack rate $\left(\mathrm{a}^{\prime}\right)=0.027$ and $c=0.000948\left(x^{2}=0.768\right.$ at $\left.5 d f\right)$.

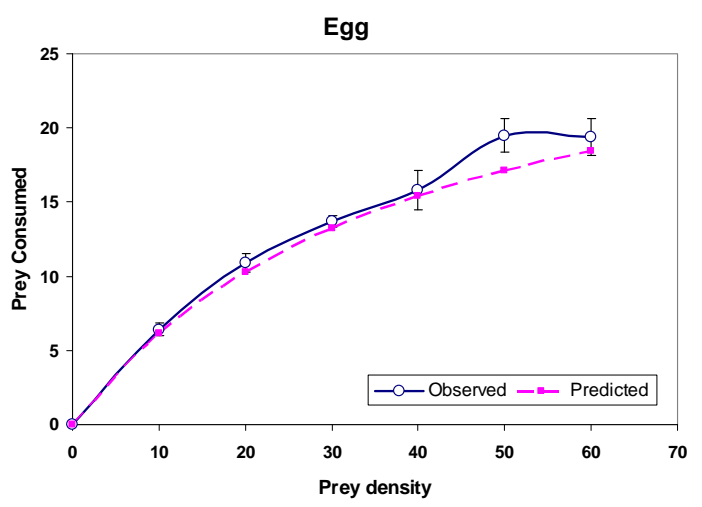

Fig. 2. The functional response of $P$. persimilis $(+)$ to eggs of $T$. urticae in 48 hours. Handling time $\left(T_{h}\right)=$ $1.561 \mathrm{hr} / \mathrm{egg}$, successful attack rate $\left(\mathrm{a}^{ }\right)=0.016$ and $c=0.00331\left(x^{2}=0.480\right.$ at $\left.5 d f\right)$.

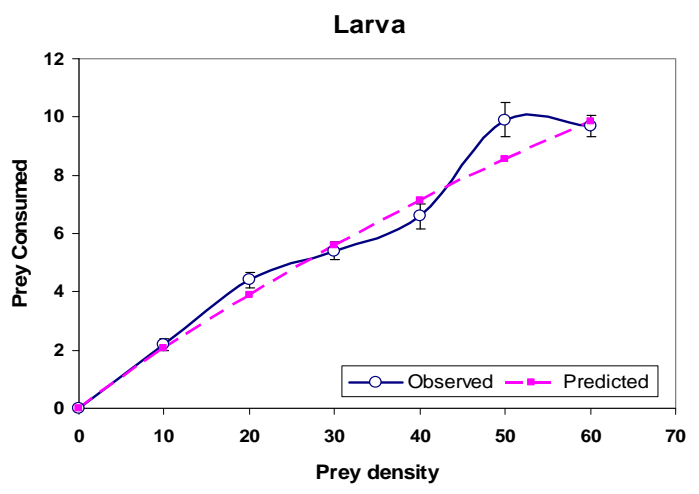

Fig. 3. The functional response of $P$. persimilis $(+)$ to larvae of $T$. urticae in 24 hours. Handling time $\left(T_{h}\right)=$ $0.580 \mathrm{hr} /$ larva, successful attack rate $\left(\mathrm{a}^{\prime}\right)=0.009$ and $c=0.0000218\left(x^{2}=0.301\right.$ at $\left.5 d f\right)$.

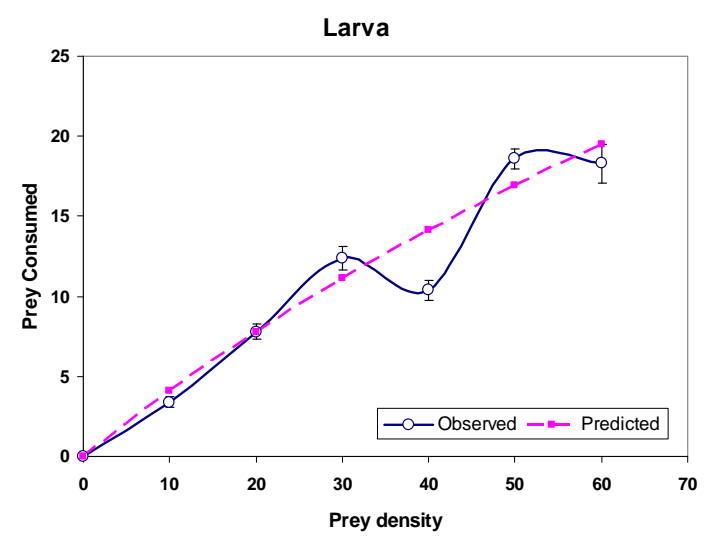

Fig. 4. The functional response of $P$. persimilis $(+)$ to larvae of $T$. urticae in 48 hours. Handling time $\left(T_{h}\right)=$ $0.614 \mathrm{hr} /$ larva, successful attack rate $\left(\mathrm{a}^{\prime}\right)=0.009$ and $c=-0.000058\left(x^{2}=1.496\right.$ at $\left.5 d f\right)$. 


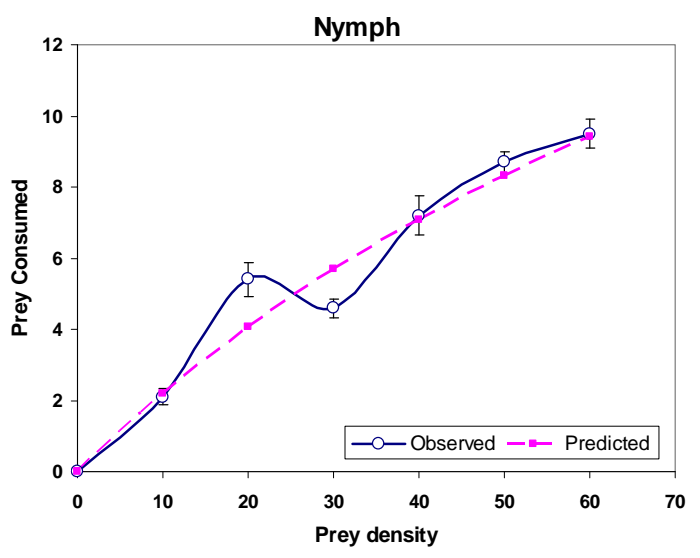

Fig. 5. The functional response of $P$. persimilis (ㅇ) to nymphs of $T$. urticae in 24 hours. Handling time $\left(T_{h}\right)=$ $0.924 \mathrm{hr} /$ nymph, successful attack rate $\left(\mathrm{a}^{\prime}\right)=0.010$ and $c=-0.000153\left(x^{2}=0.630\right.$ at $\left.5 d f\right)$.

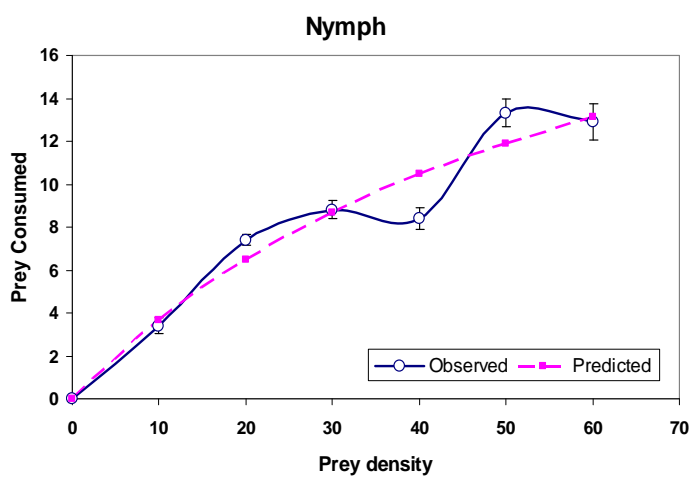

Fig. 6. The functional response of $P$. persimilis (ㅇ) to nymphs of $T$. urticae in 48 hours. Handling time $\left(T_{h}\right)=$ $1.784 \mathrm{hr} /$ nymph, successful attack rate $\left(\mathrm{a}^{\prime}\right)=0.009$ and $c=-0.000156\left(x^{2}=0.722\right.$ at $\left.5 d f\right)$.

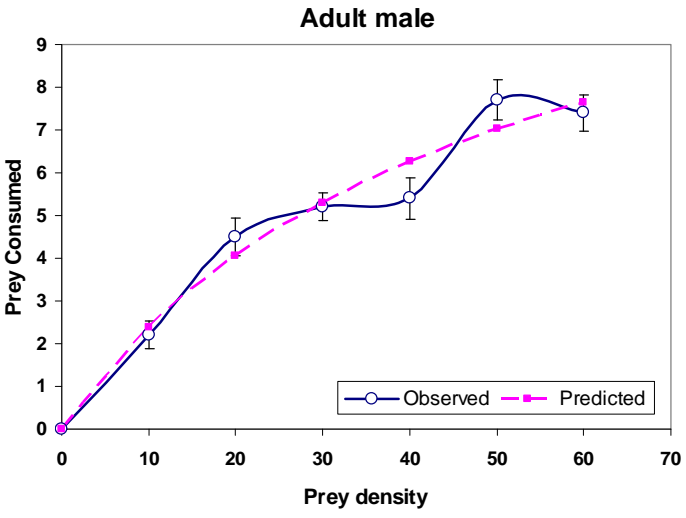

Fig. 7. The functional response of $P$. persimilis ( $(+)$ to adults $(\widehat{\delta})$ of $T$. urticae in 24 hours. Handling time $\left(T_{h}\right)=$ $1.75 \mathrm{hr} /$ adult $\left({ }^{\top}\right)$, successful attack rate $\left(\mathrm{a}^{\prime}\right)=0.012$ and $c=-0.000405\left(x^{2}=0.265\right.$ at $\left.5 d f\right)$.

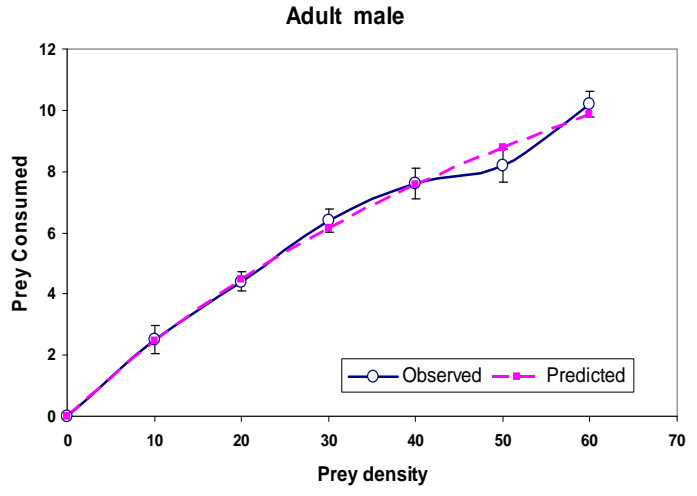

Fig. 8. The functional response of $P$. persimilis (ㅇ) to adults $(\hat{)})$ of $T$. urticae in 48 hours. Handling time $\left(T_{h}\right)=$ $1.935 \mathrm{hr} /$ adult $\left({ }^{\top}\right)$, successful attack rate $\left(\mathrm{a}^{\prime}\right)=0.00568$ and $c=-0.000684\left(x^{2}=0.064\right.$ at $\left.5 d f\right)$.

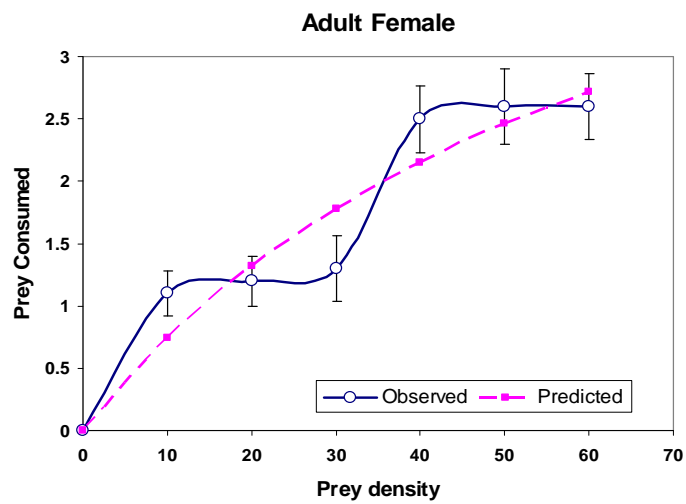

Fig. 9. The functional response of $P$. persimilis (ㅇ) to adults of $T$. urticae in 24 hours. Handling time $\left(T_{h}\right)=$ $4.16 \mathrm{hr} /$ adult $\left(+\right.$ ) , successful attack rate $\left(\mathrm{a}^{\prime}\right)=0.00357$ and $c=0.0000163\left(x^{2}=0.362\right.$ at $\left.5 d f\right)$.

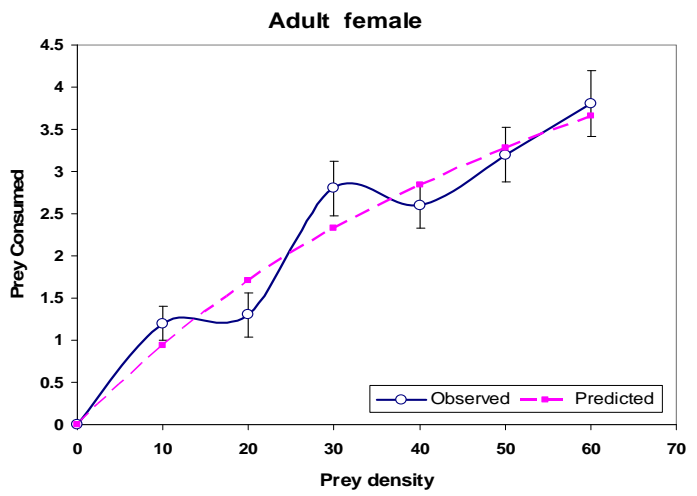

Fig. 10. The functional response of $P$. persimilis ( $(+)$ to adults (P) of $T$. urticae in 48 hours. Handling time $\left(T_{h}\right)=5.564$ hr/adult( $(+)$, successful attack rate $\left(a^{\prime}\right)=0.0022$ and $c=0.000073\left(x^{2}=0.290\right.$ at $\left.5 d f\right)$. 


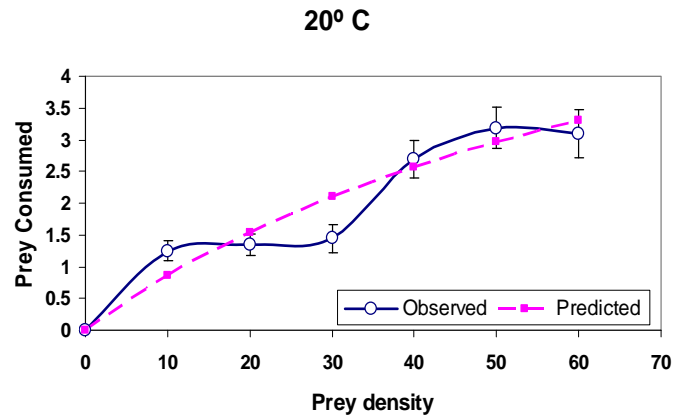

Fig. 11. The functional response of $P$. persimilis $(+)$ to $T$. urticae $(Q)$ at $20^{\circ} \mathrm{C}$. Handling time $\left(T_{h}\right)=3.110$ hr/adult, successful attack rate $\left(\mathrm{a}^{\prime}\right)=0.004$ and $\mathrm{c}=-$ $0.00037\left(x^{2}=0.441\right.$ at $\left.5 d f\right)$.

\section{$25^{\circ} \mathrm{C}$}

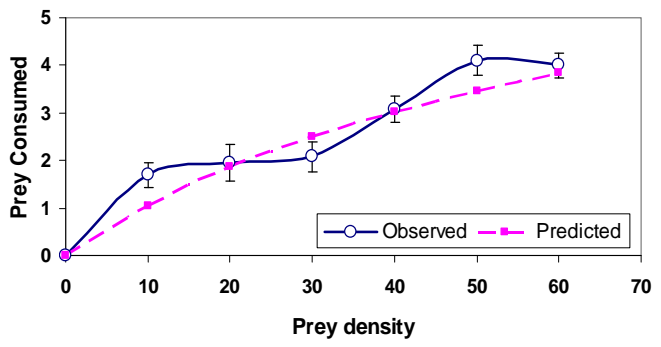

Fig. 12. The functional response of $P$. persimilis $(+)$ to $T$. urticae $(+)$ at $25^{\circ} \mathrm{C}$. Handling time $\left(T_{h}\right)=2.907$ hr/adult, successful attack rate $\left(\mathrm{a}^{\prime}\right)=.005$ and $\mathrm{c}=$ $0.000254\left(x^{2}=0.603\right.$ at $\left.5 d f\right)$.

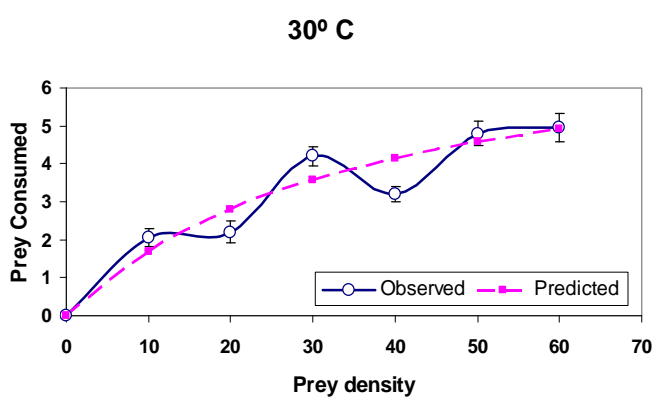

Fig. 13. The functional response of $P$. persimilis $(+)$ to T. urticae $(+)$ at $30^{\circ} \mathrm{C}$. Handling time $\left(T_{h}\right)=3.030$ hr/adult, successful attack rate $\left(\mathrm{a}^{\prime}\right)=0.009$ and $\mathrm{c}=$ $0.0000759\left(x^{2}=0.536\right.$ at $\left.5 d f\right)$.

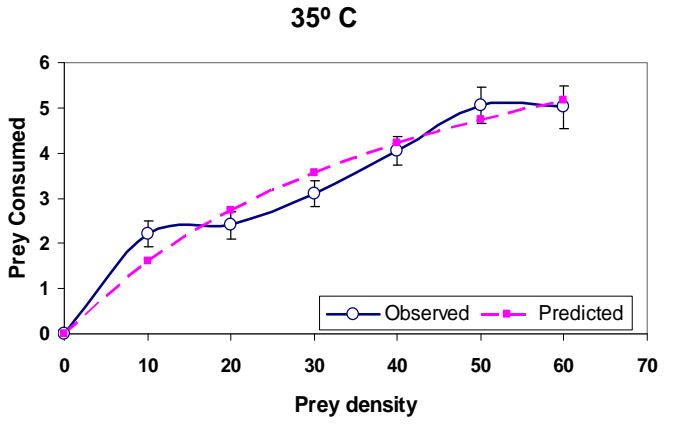

Fig. 14. The functional response of $P$. persimilis $(+)$ to $T$. urticae $(+)$ at $35^{\circ} \mathrm{C}$. Handling time $\left(T_{h}\right)=2.563$ hr/adult, successful attack rate $\left(\mathrm{a}^{\prime}\right)=0.008$ and $\mathrm{c}=$ $0.0001\left(x^{2}=0.363\right.$ at $\left.5 d f\right)$.

\section{Discussion}

According to Eveleigh and Chant (1981) the functional response of protonymphs and deutonymphs of $P$. persimilis to varying densities of protonymphs of the Pacific spider mite, T. pacificus under laboratory conditions was type II. Takafuji \& Chant (1976) observed a linear rise to a plateau (type I) for protonymphs and deutonymphs of $P$. persimilis attacking T. pacificus eggs. The linear rise to a plateau indicated that, as prey density increased, the searching efficiency of $P$. persimilis immature stages was not affected by either the hunger level of the predator and/or by the rise in the handling time of the prey by the predator (Holling, 1959, 1961; Fujii et al., 1986). According to Rasmy et al. (1991), at $22-23^{\circ} \mathrm{C}$ and $70 \% \mathrm{RH}$, protonymphs and deutonymphs of $P$. persimilis consumed 5.6 and 5.8 nymphal individuals of a mixed diet of $T$. urticae and $E$. dioscordis respectively. The functional responses of protonymphs and deutonymphs of $P$. persimilis feeding on the egg stage of $T$. urticae on bean leaves at $20^{\circ} \mathrm{C}$ and $60 \% \mathrm{RH}$ were also type II (Fernando \& Hassell, 1980). According to these authors, who studied the functional response at 8 and $24 \mathrm{~h}$ periods, the plateaus of the functional response curves were reached at approximately 2.8 and 6 prey eggs per predator protonymph, at both the initial prey density of 20 eggs per arena for 8 and $24 \mathrm{~h}$ exposure times, respectively, whereas in the case of the predator deutonymphs, these plateaus were observed at approximately 6 (at initial prey eggs of 20) and 20 (at initial prey eggs of 60) T. urticae eggs for 8 and $24 \mathrm{~h}$ experimental periods, respectively. 
All stages of $T$. urticae were consumed by $P$. persimilis. As the density of juvenile prey increased, predation also increased. The same trend was observed with the same species fed with $T$. cinnabarinus (Boisduval) (Friese \& Gilstrap, 1982) or Panonychus ulmi Koch (Jolly, 2000). Other predatory mites showed the same type of functional response (Zhang et al., 1999; Thongtab et al., 2001; Castagnoli \& Simoni, 2004). Furthermore, the present results showed that $P$. persimilis would prey more on juvenile stages than on adult male or female stages of $T$. urticae under all situations when there were ample preys. This was similar with $T$. bambusae Ehara fed with Schizotetranychus nanjingensis (Zhang et al. 1999). Again, while the food value of different prey stages are important, it appears that the dietetic value of spider mite juvenile seems to equal to that of eggs. The present study showed that the $P$. persimilis could survive at low prey density (about 10). Overall, the present study identified some characteristics listed by McMurtry (1982) for a predatory mite to be considered a successful biological control agent. The performance of $P$. persimilis was greatly affected by their food resources.

The predation model estimated in the present study reveals that the expected number of prey attacked similarly. This conclusion is supported by the fractional values of the estimated $x^{2}$ goodness of fit test, which are much lower than the table $x^{2}$ value of 11.07 at $\mathrm{P}<0.05$ with 5 degrees of freedom for both life stages and at different temperatures of this predator. This indicates the best fit of the curves presented in Figs. 1-14. Our results indicate that $P$. persimilis is highly effective at higher temperatures by significantly increasing its attack rate as well as decreasing its prey handling time. Although the effect of prey density is somewhat limited to generalize it for foraging activity of $P$. persimilis in our data, it appears to perform well on leaves with some range of prey density. $P$. persimilis can be a good biological control agent of $T$. urticae under warm conditions.

Acknowledgement: This is a part of the Ph. D. work of the first author and he acknowledges the fellowship given by the Institute of Biological Sciences, University of Rajshahi and University Grants Commission, Bangladesh for this study.

\section{References}

Abrams, P.A. 1990. The effects of adaptive behavior on the type-2 functional response. Ecology 71:877-885.

Cappuccino, N. 1992. The nature of population stability in Eurosta solidaginis, a non-outbreaking herbivore of goldenrod. Ecology 73:1792-1801.

Castagnoli, M. \& Simoni, S. 2004. Neoseiulus californicus (McGregor) (Acari: Phytoseiidae): survey of biological and behavioral traits of a versatile predator. Redia 86:153-164.

Eveleigh, E.S. \& Chant, D.A. 1981. Experimental studies on acarine predator-prey interactions: effect of predator age and feeding history on prey consumption and the functional response (Acarina: Phytoseiidae). Can. J. Zool. 59 (7):1387-1406.

Fernando, M.H.J.P. \& Hassell, M.P. 1980. Predatorprey responses in an acarine system. Res. Popul. Ecol. 22:301-322.

Friese, D.D. \& Gilstrap F.E. 1982. Influence of prey availability on reproduction and prey consumption of Phytoseiulus persimilis, Amblyseius californicus and Metaseiulus occidentalis (Acarina: Phytoseiidae). Int. J. Acarol. 8:85-89.

Fujii, K., Holling, C.S. \& Mace, P.M. 1986. A simple generalized model of attack by predators and parasites. Ecol. Res. 1:141-156.

Hassell, M.P. 1978. The Dynamics of Arthropod Predator-Prey System. (Monographs on Population Biology, 13 Ed. May, R.M.) Princeton University Press, Princeton, New Jersey, p. 237.

Hassell, M.P., Lawton, J.H. \& Beddington, J.R. 1977. Sigmoid functional responses by invertebrate predators and parasitoids. J. Anim. Ecol. 46:249262.

Holling, C.S. 1959. Some characteristics of simple types of predation and parasitism. Can. Entomol. 91(7):385-398.

Holling, C.S. 1961. Principles of insect predation. Ann. Rev. Entomol. 6:163-182.

Holling, C.S. 1965. The functional response of predators to prey density and its role in mimicry and population regulation. Mem. Entomol. Soc. Can. 45:1-60.

Huffaker, C.B. \& Messenger, P.S. 1976. Theory and practice of biological control. Academic Press, New York, 788pp.

Huffaker, C.B, van deVrie, M. \& McMurtry, J.A. 1970. Ecology of tetranychid mites and their natural enemies: a review. II. Tetranychid populations and their possible control by predators: an evaluation. Hilgardia 40:391-458. 
Hunter, A.F. \& Elkinton, J.S. 1999. Interaction between phenology and density effects on mortality from natural enemies. J. Anim. Ecol. 68:1093-1100.

Hunter, M.D. \& Price P.W. 1992. Playing chutes and ladders: heterogeneity and the relative roles of bottom-up and top-down forces in natural communities. Ecology 73:724-732.

Jolly, R.L. 2000. The predatory potential of Neoseiulus californicus: its potential as a biological control agent for the fruit tree spider mite. Panonychus ulmi. BCPC Conference, Brighton, Pest and Diseases J. pp. 487-490.

McMurtry, J.A. 1982. The use of phytoseiids for biological control: progress and future prospects. In: M A Hoy (ed), Recent Advances in Knowledge of the Phytoseiidae, pp. 23-48, Div. Agric. Sci. Univ. California Publ. 3284.

Mori, H. \& Chant D.A 1966. The influence of prey density, relative humidity, and starvation on the predaceous behavior of Phytoseiulus persimilis Athias-Henriot (Acarina: Phytoseiidae). Can. J. Zool. 44:483-491.

Murdoch, W.W. \& Oaten, A. 1975. Predation and population stability. Adv. Ecol. Res. 9:1-131.

Rasmy, A.H., Abdel-Rahman, H.A. \& Hussein, H.E. 1991. Suitability of different mite prey for the development of the predatory mite, Phytoseiulus persimilis. Exp. Appl. Acarol. 11:89-91.
Solomon, M.E. 1949. The natural control of animal populations. J. Anim. Ecol. 18:1-35.

Takafuji, A. \& Chant, D.A. 1976. Comparative studies of two species of predaceous mites (Acarina: Phytoseiidae), with special reference to their responses to the density of their prey. Res. Popul. Ecol. 17:255-310.

Taylor, R.J. 1984. Predation. Chapman \& Hall. London, $166 \mathrm{pp}$.

Thongtab, T., Chandrapatya, A. \& Baker, G.T. 2001. Biology and efficacy of the predatory mite, Amblyseius longispinossus (Evans)) as a biological control agent of Eotertranychus cendanai Rimando (Acarina: Tetranychidae). J. Appl. Entomol. 125:543-549.

Turchin, P. 1995. Population regulation: old arguments and a new synthesis. In: Cappuccino $\mathrm{N}$ and Price PW (eds), Population dynamics, pp. 19-40, Acadamic Press, London.

Zhang, Y.X., Zhang, Z.Q., Liu, Q. \& Lin, J. 1999. Biology of Typhlodromus bambusae (Acari, Phytoseiidae) a predator of Schizotertranychus nanjingensis (Acari: Tetranychidae). Syst. Appl. Acarol. 4:57-62. 